\title{
Intermédialités
}

Histoire et théorie des arts, des lettres et des techniques

Intermediality

History and Theory of the Arts, Literature and Technologies

\section{"llusions of Absence:" Disappearances, Displacements, and the Limits of Responsibility in The Winter's Tale and The Remains of the Day}

\section{Susan Bruce}

Numéro 10, automne 2007

Disparaître

Disappearing

URI : https://id.erudit.org/iderudit/1005554ar

DOI : https://doi.org/10.7202/1005554ar

Aller au sommaire du numéro

Éditeur(s)

Centre de recherche sur l'intermédialité

ISSN

1705-8546 (imprimé)

1920-3136 (numérique)

Découvrir la revue

Citer cet article

Bruce, S. (2007). "llusions of Absence:” Disappearances, Displacements, and the Limits of Responsibility in The Winter's Tale and The Remains of the Day.

Intermédialités / Intermediality, (10), 77-94. https://doi.org/10.7202/1005554ar
Résumé de l'article

Cet essai a pour sujet la disparition de personnages dans deux textes différents : Ruth et Sarah, les deux domestiques juives expulsés de Darlington Hall, dans The Remains of the Day de Kazuo Ishiguro ainsi que Mamillius, héritier de Léonte, roi de Sicile, qui meurt dans l'acte deux de Winter's Tale de Shakespeare. Ces personnages sont si définitivement effacés du texte (où ils n'apparaissent que brièvement), que c'est comme si celui-ci les faisait " disparaître ». Selon nous, par leur absence, ces personnages sont d'autant plus remarquables. Bien qu'on leur refuse la présence, ces personnages ne disparaissent pas simplement. Ils ne partent pas tout à fait : ils résident plutôt dans le regard du lecteur, et leur apparente absence perturbe l'illusoire complétude dans laquelle se terminent les deux textes. Ce déplacement, du texte au regard, entraîne selon nous des conséquences d'ordre éthique pour le lecteur ou le spectateur. Incapable de laisser reposer ces fantômes comme les protagonistes du texte semblent, eux, capable de le faire, le lecteur est forcé de penser au problème de la responsabilité, non par ce qui est présent dans le texte, mais plutôt par ce qui n'y est plus. 


\title{
"Illusions of Absence:" Disappearances, Displacements, and the Limits of Responsibility in The Winter's Tale and The Remains of the Day
}

\author{
Susan Bruce
}

\section{The Remains of the Day: Ruth and Sarah}

“Lord Darlington wasn't a bad man. He wasn't a bad man at all. And at least he had the privilege of being able to say at the end of his life that he made his own mistakes. [...] As for myself, I cannot even claim that. [...] I can't even say that I made my own mistakes. Really_one has to ask oneself-what dignity is there in that?"1

So crescendos the brief conversation on the bench on Weymouth pier at the end of The Remains of the Day, when Mr. Stevens, in a rare moment of bleak self-reckoning, confronts momentarily the essence of his wasted life in his acknowledgement that he "can't even say that [he] made his own mistakes." This deceptively simple sentence raises profound ethical questions, for Mr. Stevens' anguish here, (and by extension the reader's empathetic grief, although I will shortly seek to complicate such identifications) stems from a recognition which is complex indeed. What might it mean, to make someone else's mistakes? Through the course of this novel we have been brought gently to a point where we may not even notice the oddity of what moves us (for this conversation is nothing if not moving) nor question the truth of something whose implications, were we to stop and think about them, we might find incomprehensible, a syntactical fault. In

1. Kazuo Ishiguro, The Remains of the Day, London and Boston, Faber and Faber, 1993 , p. 243. Henceforth, references to this text will be indicated by the initials "RD," followed by the page number, and placed in parentheses in the body of the text. 
ordinary English, where our mistakes can only be our own, this locution makes no sense. Surely, one cannot really make someone else's mistakes? ${ }^{2}$

That, despite the idiomatic strangeness of the moment, the reader of Ishiguro's novel experiences Mr. Stevens' locution not as an error but as a devastating truth, speaks to the complexity of The Remains of the Day and to the capacity of fiction to change one's mind, or at least significantly to challenge one's preconceptions about really important things. It also points to the way in which Kwame Anthony Appiah's assessment of the novel, in his recent Critical Inquiry essay on liberalism and identity, gets it wrong. Appiah criticises Ishiguro for something which, he implies ("the novel cheats," he says [emphasis mine]), is a shortcoming-aesthetic, intellectual, even moral. Appiah argues that Mr. Stevens' life is a failure because "he is and intends to be servile" where "servility entails [...] behaving like a slave [...] whose will is somehow subjected to another's." "But," Appiah goes on:

$[\ldots]$ the novel cheats in its argument against this form of servility. Ishiguro [...] obscures the relationship between dignity and individuality by conflating servant and slave; he prevents us from seeing that it is servility, not service, that is undignified. ${ }^{3}$

The distinction Appiah employs here is at base economic: a servant is, at least in law, free to choose not to serve his master- he can resign-, whereas a slave is not. One need not be overly Althusserian about service to remark that the apparent freedom of the servant is more complex than it might on the face of it seem, and as I shall try to show, The Remains of the Day is humanely sympathetic to the limitations servitude apparently hedges around agency, as well as firm in its conviction that resistance to injustice, at least in the form of a right to resign, remains a real possibility for most of us, whomever, or whatever, we serve. Service per se is not characterised as undignified in the novel (Remains offers us at least one representation of a servant [Miss Kenton] whose dignity at crucial moments in the text-even when she is wrong-remains unquestioned in it); more importantly, although something like servility is one of the novel's organising concepts, "servility" is in some respects an unhelpful term. It skates over distinctions which the novel does not take so lightly, such as those between holding an opinion, voicing it, and acting on it. And it is almost always used to qualify someone else:

2. One can of course say, "I made his mistake," meaning: "I made the same mistake as he." But this is not what Mr. Stevens means.

3. Kwame Anthony Appiah, "Liberalism, Individuality and Identity," Critical Inquiry, Vol. 27, No. 2, winter 2001, p. 315 . 
it does not lend itself to self-reflexivity. ${ }^{4}$ Its employment almost inevitably bolsters a self/other distinction, and for this reason, as well as for its inhospitality to questions to which I will later return (such as: "is it worth having an opinion if you do not voice it, or voicing it if you do not act upon it?") it can obscure the questions which the novel wants to scrutinise and to test.

For in fact, Ishiguro is at pains to examine how it can happen that service can slip into servility, an illustration which entails a closer connection between Stevens and his readers than some critics of the text, Appiah included, have allowed. For another misreading of the novel is one which takes Stevens to be some kind of realist representation of an anachronistic servant, ${ }^{5}$ whose dilemmas and problems are not ones we ourselves would be likely ever to face. Ishiguro did not intend Stevens as an Other to the reader in this way; rather, he thinks of him, he says, as "a good metaphor for the relationship of very ordinary, small people to power" (holding that most of us are, like Stevens, exactly that: very ordinary, small people). What then are we to make of the fact that in some respects the text does encourage this kind of apprehension of distance between Stevens and the reader, not least in its construction of an implied audience of other butlers? Stevens' invitation to his reader to sympathise with his anxieties over his staff plan, for instance, is at once comical and distancing in its assumption that the reader expends a good deal of time thinking about his (I use the pronoun intentionally: the implied narratee is male) staff plan. "You will no doubt agree that the very best staff plans are those which give clear margins of error" (RD, p. 8) Stevens observes; this kind of comment in fact invites disagreement, not the consensus that Stevens anticipates. We don't spend a lot of time thinking about the quality of staff plans, because we are not butlers (some of us, indeed, are not

4. The etymology of the word "servility" renders its contemporary usage problematic: the etymology-like a slave-disparages through analogy to a state which now inspires sympathy, not contempt. We would not, for instance, use the term of an indentured labourer, or a woman trafficked into the sex trade. This is not to begin to speak of issues such as the relation of servility to self-deception, or in turn the relation between selfdeception and intention. It is, for example, far from self-evident at what level Mr. Stevens can, as Appiah claims he does, "intend to be servile" (p. 315, italics mine).

5. For discussions of the novel's relation to realism see for instance Ben Howard, "A Civil Tongue: The Voice of Kazuo Ishiguro," Sewanee Review, Vol. 109, No. 3, 2001, p. 398-417, and Frederick M. Holmes, "Realism, Dreams and the Unconscious in the Novels of Kazuo Ishiguro," in James Acheson, Sarah C. E. Ross (eds.), The Contemporary British Novel, Edinburgh, Edinburgh University Press, 2005, p. 11-20.

6. Ishiguro, quoted in Adam Parker, Kazuo Ishiguro's The Remains of the Day: A Reader's Guide, New York, London, Continuum Press, 2001, p. 54. 
even male). Such preoccupations being foreign to us, we can't "agree" with Stevens here (or indeed disagree with him). His assumptions that we will measure instead the distance between us, because he is assuming that we are someone we are not; in this way, the relationship Stevens implies generates a kind of denial in the reader which takes the form "but I am not a butler."

But this denial can become denial in another, deeper sense, if we allow it too much sway. There is a complex paradox at work here, wherein too stringent a rejection of our similarity to Stevens can end up producing precisely the kind of self-deception that Stevens himself is prey to, the very assertion of our difference from him acting to make us similar to him if we persist too strongly in seeing the dilemmas that Stevens presents us with as someone else's kind of problem. Where, for instance, lie the boundaries of the "we" in the following clause, which is also addressed by Stevens as one butler to another: "we must be careful not to attempt to deny the responsibility which ultimately lies with ourselves?" (RD, p. 35) As Phelan and Martin point out, the complexity of Stevens' narration places his audience in "a challenging ethical position". ${ }^{8}$ To some degree, Stevens is a figure for the reader, as well as a counter to her. The Remains of the Day sets up the action as if we were simply passive eavesdroppers on the story of Stevens' life, but manipulates the relation between narrator and reader so that we become increasingly encouraged to ask ourselves the questions which Stevens refuses to answer. Deftly conflating questions of personal and political responsibility, the novel ultimately challenges the reader to address those questions herself. And the way in which the text manages the displacement of such questions of responsibility from narrator to narratee is its deployment of a textual disappearance at its centre, a disappearance which, although underplayed, even apparently forgotten in the margins and conclusions of the text, is fundamental to the novel's meaning: the fulcrum, as it were, of its ethical force.

That disappearance is initiated when Lord Darlington, in his role as facilitator of the appeasement of the Nazis, calls Stevens into his study to instruct him to dismiss the two Jews on his staff:

7. For arguments of this nature see Rebecca Suter, “We're Like Butlers:' Interculturality, Memory and Responsibility in Kazuo Ishiguro's The Remains of the Day," Q/W/E/R/T/Y, Vol. 9, 1999, p. 244; and Andrew Teverson, "Acts of Reading in Kazuo Ishiguro's The Remains of the Day," Q/W/E/R/T/Y, Vol. 9, 1999, p. 257-258.

8. James Phelan and Mary Patricia Martin, “The Lessons of 'Weymouth': Homodiegesis, Unreliability, Ethics and The Remains of the Day," in David Herman (ed.), Narratologies: New Perspectives on Narrative Analysis, Columbus, Ohio University Press, 1999, p. 88-109. 
"I've been doing a great deal of thinking, Stevens. [...] We cannot have Jews on the staff here at Darlington Hall."

"Sir?"

"It's for the good of this house, Stevens. [...] I've looked into this carefully, Stevens, and I'm letting you know my conclusion."

"Very well sir."

"Tell me, Stevens, we have a few on the staff at the moment. Don't we? Jews, I mean."

"I believe two of the present staff members would fall into that category, sir."

"Ah." His lordship paused for a moment, staring out of his window. "Of course, you'll have to let them go."

"I beg your pardon, sir?" (RD, p. 146-147)

Immediately after the conclusion of this conversation, Mr. Stevens proceeds to inform Miss Kenton that he will, the following day, dismiss Ruth and Sarah. She reacts as he did not:

"Does it not occur to you, Mr. Stevens, that to dismiss Ruth and Sarah on these grounds would be simply-wrong? I will not stand for such things. I will not work in a house in which such things can occur $[\ldots]$

I am warning you, Mr. Stevens, I will not continue to work in such a house. If my girls are dismissed, I will leave also. [...]

I am telling you, Mr. Stevens, if you dismiss my girls tomorrow, it will be wrong, a sin as any sin ever was one and I will not continue to work in such a house." (RD, p. 149)

And yet: Ruth and Sarah are dismissed; Miss Kenton puts up no opposition. Although "for some days following the dismissal of the employees" she is "extremely cold" to Mr. Stevens (RD, p. 150) she says nothing beyond, once, the re-iteration of her intention to hand in her notice, which she does not do. She does not leave. More than a year after the event, Mr. Stevens tells us, the "matter" came up "one last time" when Darlington expresses his regret about the incident, and instructs Stevens to see if he can find Ruth and Sarah to recompense them for what had happened. It is of course too late for that. Ruth and Sarah have gone, and beyond relating a final conversation with Miss Kenton about the matter, in which she expresses her anguish at having done nothing, Mr. Stevens says no more about them. On page 154 they vanish from the text for good, as absolutely as they have from Darlington Hall.

Inhabiting just eight pages of a 245 page novel, Ruth and Sarah might appear inconsequential in the grand scheme of The Remains of the Day. Yet of course, they are not. Their ghosts pace the unspoken borders of Mr. Stevens' self-protective prose, call out to be remembered against a text that apparently forgets them, haunt that conversation on the bench at Weymouth pier. They are 
the embodiment of the problem with which I began: it is their disappearance, unspoken, unacknowledged, "by and large, forgotten" by the characters in this narrative (RD, p. 150), which is "someone else's mistake," the crucial, desperate, shameful mistake that Mr. Stevens regrets so deeply at the novel's conclusion that he cannot even acknowledge it as his own, or bring them back, even into language, at the end of the day. It is as if they have been "disappeared" by the novel, in a callous, if aesthetic, repetition of the manner in which so many human beings have been "disappeared" by the regimes they oppose in the zoth century. But how is it that characters who are afforded so little physical space in a text, or even in the manifest consciousness of a text's protagonist, can play so large a part in the mind of the text's readers? How is it that they can haunt the boundaries of a narrative, refuse to be banished from it, even when they are incidental to its plot, and banished from its prose? How do they deny the text's authority to make them disappear, to "disappear" them? And what resonance does their disappearance hold for the complex issues of responsibility that The Remains of the Day addresses? I want now to find a way of approaching some of these questions by way of a brief dialogue with a much earlier text and with those who have addressed it, a text which shares almost nothing with Remains except for the fact that it fails to restore what is lost, "disappearing" some of its characters even from the memory of those they leave behind.

\section{THE WINTER'S TALE: MAMILLIUS.}

For many years, now a broad critical consensus on The Winter's Tale has read the play as a romance or a tragi-comedy, accentuating in it a movement from apparently tragic opening to reconciliatory, joyous, outcome, the magical comingto-life of Hermione-as-statue an art, in Leontes' words, as "lawful as eating". 9 The play $^{10}$ may open with Leontes' self-destructive jealousy, but it closes, according to

9. William Shakespeare, The Winter's Tale, Stephen Orgel (ed.), Oxford, Oxford University Press, 1996 [1611], Act 5, Sc. 3. p. 110-11. Henceforth, references to this text will be indicated by the initials "WT," followed by the line reference and placed in parentheses in the body of the text.

10. As The Winter's Tale opens, Leontes, King of Sicilia, attempts to persuade Polixenes, his childhood friend and the King of Bohemia, to prolong his nine month visit to Sicily. Failing, he instructs his heavily pregnant Queen, Hermione, to try her luck. She succeeds; Leontes falls into a sudden access of jealousy. He confides in his servant Camillo, asking him to poison Polixenes; Camillo agrees, but warns Polixenes, who flees with Camillo. Act 2 opens with the heavily pregnant Hermione playing with her young son Mamillius; Leontes accuses Hermione of carrying Polixenes' child. He imprisons her, despite the protests of his courtier, Antigonus, that Hermione is innocent, and sends two courtiers, Cleomenes and Dion, to the Oracle for the truth. Hermione is delivered 
most, with the restitution of that which was lost (Perdita) and the reconstitution of the patriarchal royal family. Dowden, the first to confer upon the text the generic label of "romance," saw it as possessing "a sweet serenity"11 and his perception of the play's conclusory tone has been echoed by critics of very different theoretical persuasions for more than a century now. J. H. P. Pafford, in 1963, held that the experience of the play "is [...] one of disaster resolving to tranquillity" (p. lx), the ending of the play "[restoring] most of the good [...] and [... bringing] about [...] reconciliation among [...] nearly all concerned."12 (p. lxviii) In the 1980s, Northrop Frye understood the play to rehearse a metamorphosis from the bleakness of

of an infant daughter; Antigonus and his wife Paulina bring the babe, named Perdita, to Leontes, vigorously defending Hermione's innocence, but Leontes instructs that the babe be taken hence and consumed with fire. He arraigns Hermione, who defends herself with great dignity; Cleomenes and Dion arrive with the pronouncement of the oracle: "Hermione is chaste, Polixenes blameless, Camillo a true subject, Leontes a jealous tyrant, his innocent babe truly begotten, and the King shall live without an heir if that which is lost be not found" (WT, Act 3, Sc. 2, p. 131-34). Leontes denies the Oracle, upon which a servant enters declaring that Mamillius is dead. Hermione collapses and is carried offstage. Leontes' jealousy evaporates, but it is too late: Paulina enters, lamenting the death of Hermione. Leontes vows to mourn his wife and son for the rest of his days.

Meanwhile, Antigonus has taken the baby Perdita to Bohemia, where he abandons her, and is eaten by a bear ("Exit, pursued by a bear" is the infamous stage direction). Time passes (personified, in the form of a chorus announcing a 16 year gap); brought up by a shepherd, Perdita meets and falls in love with Florizel, son of Polixenes. Polixenes, furious at what he sees as his son's betrayal in marrying beneath him, accosts Florizel at his wedding and threatens to deny him his inheritance if he does not abandon Perdita. Florizel and Perdita flee with Camillo to Sicilia.

Meanwhile, back in Sicily, Leontes has resisted the blandishments of Cleomenes and Dion to re-marry, agreeing instead to allow Paulina to govern the giving of his hand. Florizel and Perdita arrive; we see them meet with Leontes, but the revelation of Perdita's identity is reported, not shown. Also reported is news of a statue of Hermione, executed by "that rare Italian master, Giulio Romano" (WT, Act 5, Sc. 2, v. 94 ). The last scene of the play sees the re-united Leontes, Polixenes, Perdita, Florizel, Camillo and Paulina gather to view this statue, which, some fifty lines from the end of the play, awakes, descends from its pedestal to embrace Leontes and address her daughter. Leontes concludes the play with the instruction to Camillo and Paulina to marry, and leads all away to tell their separate stories.

11. Edward Dowden, Shakespeare, London, Macmillan and co., 1877, quoted by Stephen Orgel in WT, p. 3.

12. J. H. P. Pafford, in William Shakespeare, The Winter's Tale, J. H. P. Pafford (ed.), London, New York, Routledge Press, 1966. 
winter to the promise of spring,,$^{13}$ and C. L. Barber and Richard P. Wheeler maintained that "the shift from tragedy to romance [at the end of Shakespeare's career] comes to restore a sense of the magical and sacred in human experience,"14 akin to "the action of successful mourning, in which the lost beloved is recovered as an inner presence and the mourner is free to turn anew towards worldly objects." (WJ, p. 334) Even Howard Felperin's sophisticated deconstructive treatment of the text came to rest, finally, in resolution and acceptance, arguing that:

$[\ldots]$ the very opacity that had been such a problem in the language of the opening act becomes $[\ldots]$ the means of resolving that problem. If we cannot know except through the dark glass of language, we might as well accept what is a necessary limitation on our knowledge. Like Leontes [...] we may even [...] come to welcome this uncertainty as ground for belief: "If this be magic, let it be an art / As lawful as eating." 15

Even more recently, although Stephen Orgel wants to "abandon the category of romance," and "the fiction of Shakespeare [...] declining into a serene old age and producing a drama of wisdom, reconciliation and harmony," (WT, p. 6) he too subscribes eventually, like most of his critical forebears, to a reading which settles in restoration. For Pafford, what was restored at the conclusion of The Winter's Tale is the quality of "good;" for Barber and Wheeler, what returns is "a sense of the magical and sacred in human experience;" for Orgel, "what is restored, finally, in this quintessentially Jacobean drama, is royal authority." (WT, p. 79)

What almost all readings of the play propose, then, is an understanding which tacitly adopts not only the joyous celebratory tone with which Leontes concludes the play, but also the pragmatic, rather managerial assumptions of his male courtiers, who hold that there exists something akin to an economy of regret, within which losses consequent on the mistakes of one's past can be laid to rest, not just forgiven but also, ideally, forgotten. The first scene of the play's final act explores this assumption by way of a discursive contest between Paulina, Cleomenes and Dion, over the propriety of memory or forgetting, fault or redemption, mourning or melancholia. "Sir," Cleomenes starts:

13. Northrop Frye, Northrop Frye on Shakespeare, Robert Sandler (ed.), Newhaven, Yale University Press, 1986.

14. C. L. Barber, Richard P. Wheeler, The Whole Journey: Shakespeare's Power of Development, Berkeley, University of California Press, 1986, p. 298. Henceforth, references to this text will be indicated by the initials "wJ," followed by the page number, and placed in parentheses in the body of the text.

15. Howard Felperin, “'Tongue-Tied our queen?': The Deconstruction of Presence in The Winter's Tale," in Patricia Parker, Geoffrey Hartman (eds.), Shakespeare and the Question of Theory, New York, London, Methuen, 1985, p.3-18, 16. 
You have done enough, and have perform'd

A saint-like sorrow: no fault could you make

Which you have not redeem'd; indeed, paid down

More penitence than done trespass: at the last,

Do as the heavens have done, forget your evil;

With them forgive yourself (WT, Act 5, Sc. 1, v. 1-6)

Dion and Cleomenes are motivated here by anxiety over the succession: it is the "dangers, by his highness' fail of issue, / [that] may drop upon his kingdom and devour / Incertain lookers on" (wT, Act 5, Sc. 1, v. 27-29) that the two courtiers fear, should the king fail to remarry and produce an heir. Paulina's words, of course, are motivated by her knowledge that Hermione lives. But whilst the male courtiers adopt a strategy of persuasion that seeks to negate the past and its consequences, rewriting attempted infanticide and the mortal suffering of Mamillius into something more discrete-"fail of issue"-Paulina's words are arguably in excess of what is necessary to accomplish her design. She does not merely dissuade Leontes from remarrying, but acts also as the scourge of his memory, refusing to let the past go, or to allow Leontes to evade the real nature of his responsibility: "she you kill'd" she reminds the King (WT, Act 5, Sc. 1, v. 15); and later, she eggs on Leontes' painful fantasy of the ghost of the dead Hermione returning tortured by his imagined remarriage, and in turn torturing him for forgetting her, shrieking, "Remember mine" (WT, Act 5, Sc. 1, v. 6o).

Clearly, one of the things that is going on in this scene is a gendered competition between male and female courtiers over the body and the will of the King. This is a competition which Paulina 'wins': Leontes is not allowed to remarry until Paulina tells him that he may; Cleomenes and Dion fail in their attempt to erase the past from the collective memory (for which Leontes' memory surely stands in this instance). It is, then, a little surprising that so many accounts of the play, as we have seen, tacitly embrace the courtiers' perspective, insisting that the movement of the play is unilinear, forward directed, leaving behind a troubled past in its passage to a brighter future, the forgetting of past evil and loss a necessary corollary to the forgiveness of the self. In adopting this perspective, such accounts fail properly to answer the questions which the debate (in urgent tones) foregrounds, not least in the figurative language the parties in it employ. What does it mean to do "enough" for one's past sins? How much sorrow and repentance can account for a gross or an evil action? Cleomenes' words, like Dion's, are littered with the language of exchange and comparisons: ${ }^{16}$ faults weighed by redemption, trespasses paid down in penitence, the state weighed against "fail of

16. For a provocative discussion of this language, see Stanley Cavell, Disowning Knowledge in Six Plays of Shakespeare, Cambridge, Cambridge University Press, 1987, p. $193-221$. 
issue," the holiness of a revived Hermione outweighed by that of "royalty's repair," past evils and sorrows subordinate to "present comfort" and to "future good," forgiving and forgetting earned, in the end, by the "performance" of a "saint-like sorrow," as if regret were reducible to a ritual. But can one "pay down" penitence to redeem one's trespasses: is the language of restitution, retribution, accounting for, paying back, an adequate language to express Leontes'-and perhaps more pertinently, the play's - dilemma? It would seem not, from this dialogue and its outcome. Paulina's words reject such accounts of sin and repentance: they deny the very basis of the discourse which Cleomenes and Dion invoke. For Paulina there is no possibility of such parallels, of finding comparable value in other possibilities; for her "there is none worthy / Respecting her that's gone." (WT, Act 5, Sc. 1, v. 35)

And of course, The Winter's Tale brings the dead Queen back, transforming a dead, static media into a living, moving being, as Hermione steps down from the podium and "hangs about his neck" (WT, Act 5, Sc. 3, v. 111), an action which implicitly counters Cleomenes' and Dion's language of exchange, and endorses Paulina's rejection of the rhetoric of replacement. This is the play's great restoration, art transforming itself into life, a statue displaced by a living breathing Hermione. The attention paid by the play to the moment of this transformation from one medium (stone) to another (flesh), as well as its importance in productions of the play in the theatre has been the source of a great deal of critical reflection: ${ }^{17}$ the transition, played out over 155 lines, is not only the climactic moment of the play's resolution, but a dramatic enactment of the power of what is liminal and in-between to move those (off as well as on the stage) who witness it. The moment where stone metamorphoses into flesh places in suspension a whole range of oppositions, and troubles the separation of their poles: the quick and the dead, the magic and the real, art and life. Looking upon the statue, Leontes expresses the way in which, even in the moment of its revelation, as Paulina pulls back the curtain to expose it to our gaze, it challenges the stability of such familiar polarities: "Oh thus she stood," he exclaims, remembering Hermione when he courted her, "even with such life of majesty-warm life, / As now it coldly stands-when first I woo'ed her," and yet no sooner has he uttered these words that he deconstructs them:

I am ashamed. Does not the stone rebuke me

For being more stone than it? O royal piece!

There's magic in thy majesty, which has

My evils conjured to remembrance, and

17. See for instance Leonard Barkan, “'Living Sculptures': Ovid, Michaelangelo and The Winter's Tale" ELH, Vol. 48 (1981), 639-667. For a brief account of "the statue in the theatre" see Orgel, 62-77. 
From thy admiring daughter took the spirits

Standing like stone with thee. (WT, Act 5, Sc. 3, v. 35-42)

Even the surface of the statue comes to represent the porosity of the boundaries between conventional oppositions, for the statue, we learn, is painted: "but newly fixed; the [colour] / Not yet dry," as Paulina puts it (WT, Act 5, Sc. 3, v. 4546). "The ruddiness upon her lip is wet" she tells Leontes, "You'll mar it if you kiss it, stain your own, / With oily painting" (WT, Act 5, Sc. 3, v. 80-82). Well may Leontes remark that "the fixture of her eye has motion in't, / And we are mocked with art." (WT, Act 5, Sc. 3, v. 66-67) And yet of course in the end they are not "mocked with art:" art instead keeps the tacit promise that it makes, and becomes the vehicle through which Hermione really is restored, to motion and to speech and to her family. ${ }^{18}$

But some losses in The Winter's Tale are not recuperated. Antigonus' exit, pursued by a bear, may afford some farcical comedy but his death is brutal for all that: "to see how the bear tore out his shoulder-bone, how he cried to me for help and said his name was Antigonus," (WT, Act 3, Sc. 3, v. 94-97) relates the clown; "how the poor souls roared, and the sea mocked them: and how the poor gentleman roared, and the bear mocked him, [...] the men are not yet cold under the water, nor the bear half dined on the gentleman: he's at it now." (wT, Act 3, Sc. 3, v. 98-105) The relation of this incident may veer from the tragic quality of the first two acts to a kind of grotesquerie those acts do not own, but there is an underlying brutality here that is ill-explained by (for instance) appeals to dramatic expediency. ${ }^{19}$ Surely, Shakespeare might have found a less gruesome demise for Antigonus; surely, too, had he wanted, he could have returned him to Sicily. After all, he manages stranger things with Perdita and Hermione. More seriously still, Mamillius is dead of shame, and will never, unlike his mother and sister, return. Leontes has, through his actions, lost his heir, a "gentleman of the greatest promise that ever came into $[\ldots]$ note, $[\ldots]$ a gallant child $[\ldots]$ that $[\ldots]$ physics the subject, makes old hearts fresh" (wT, Act 1, Sc. 1, v. 35-39); this is a loss which can never be recovered. Paulina mentions Mamillius ("jewel of children") just before the entrance of Florizel, to which Leontes instructs her to "cease; [...] / He dies to me again when talked of" (wT, Act 5, Sc. 1, v. 116-119). Thereafter, he is simply erased from the drama. Like Ruth and Sarah, he just disappears. No one

18. Hermione tells us that "knowing by Paulina that the oracle / Gave hope [Perdita] wast in being," she "preserved [herself] to see the issue" (WT, Act 5, Sc. 3, v. 126-127); a touch of realism thus "explains" the magic as lawful as eating.

19. Pafford argues that Shakespeare "introduces [Antigonus] largely to make plausible the deposit of the babe, and then has to dispose of him on shore." (J. H. P. Pafford, in William Shakespeare, The Winter's Tale, p. lxiv) 
mentions him again; there is no indication, even, that any remembrance of him lingers to mar the reconciliatory joy of the drama's conclusion.

Few have taken Mamillius' disappearance from the text seriously enough to argue that we should continue to lament him when his parents have apparently recovered from his loss. But Edward Hall's Propeller Theatre's 2005 production of the play, which had the actor who played Mamillius (Tam Williams) double as Time and as Perdita, may suggest that perhaps the time is ripe for different, less complacent, accounts of the play to find their moment: this was a production which, in the words of the Guardian reviewer, was "framed as a nightmare of family disintegration experienced by the doomed young prince, Mamillius." ${ }^{\circ}$ And despite the hegemony of the "romance" reading of The Winter's Tale, some critical voices linger to remind us - so in danger, like Leontes, of forgetting-of the stark irrecuperability of the very major loss which the play never, at its very end, calls into its accounts. The best and most moving of these remains one from another century: Swinburne's response to The Winter's Tale which is, like Mamillius himself, largely, and undeservedly, forgotten. But for its emotional engagement with the problem of Mamillius' disappearance, and its strikingly intelligent insights about the play's closing act, Swinburne's account of the text is worth hearing again. Here is what he said:

The wild wind of The Winter's Tale at its opening would seem to blow us back into a wintrier world indeed. And to the very end I must confess that I have in me so much of the spirit of Rachel weeping in Ramah as will not be comforted because Mamillius is not. It is well for those whose hearts are light enough, to take perfect comfort even in the substitution of his sister Perdita for the boy who died of "thoughts high for one so tender." Even the beautiful suggestion that Shakespeare as he wrote had in mind his own dead little son still fresh and living at his heart can hardly add more than a touch of additional tenderness to our perfect and piteous delight in him. And even in her daughter's embrace it seems hard if his mother should have utterly forgotten the little voice that had only time to tell her just eight words of that ghost story which neither she nor we were ever to hear ended. Any one but Shakespeare would have sought to make pathetic profit out of the child by the easy means of showing him if but once again as changed and stricken to the death for want of his mother and fear for her and hunger and thirst at his little high heart for the sight and touch of her: Shakespeare only could find a better way, a subtler and a deeper chord to strike, by giving us our last glimpse of him as he laughed and chattered with her "past enduring," to the shameful neglect of those ladies in the natural blueness of whose eyebrows as well as their noses he so stoutly declined to believe. And at the very end (as aforesaid) it may be that we remember him all the better because the

20. Lyn Gardner, The Guardian, 2005, quoted on the British Council Website, www. britishcouncil.org/china-arts-ukinchina-drama-aboutpropeller-2.htm. 
father whose jealousy killed him and the mother for love of whom he died would seem to have forgotten the little brave sweet spirit with all its truth of love and tender sense of shame as perfectly and unpardonably as Shakespeare himself at the close of King Lear would seem to have forgotten one who never had forgotten Cordelia. ${ }^{21}$

It is to the implications of this passage that I wish in conclusion to turn.

\section{BRIEF ENCOUNTERS}

Swinburne's comments speak better than anything else I have read to my own sense of The Winter's Tale, wherein the memory of Mamillius lingers at the end of the play: a dead boy, unacknowledged, apparently forgotten by the very people who ought most religiously to remember him, glimpsed so poignantly, and then just lost, despite his intrinsic connection with the very title of the play. As Swinburne implies in his reference to "the little voice that had only time to tell her just eight words of that ghost story which neither she nor we were ever to hear ended," Mamillius is a figure who foregrounds issues of curtailment or abbreviation: his "stories" - the one that he starts to tell and the one that he so briefly lives,-are alike cut short, arrested, ended before any of us have heard quite enough. That the unfinished tale he starts to tell is a homonym of the play itself ("a sad [tale], best for winter" [WT, Act 2, Sc. 1, v. 25]) is perhaps one more reason to doubt the absolute authority of the consensus that has dominated accounts of the play. The economistic recourse taken by "those whose hearts are light enough" to the satisfaction of substitutions might find itself slightly troubled by the shadow of that other, incomplete, winter's tale in the play's second act. And however reconciliatory and joyous Hermione's restitution is, that transformation from stone to living being also quietly emblematises loss: "but yet, Paulina," says Leontes, "Hermione was not so much wrinkled, nothing / So aged as this seems." (WT, Act 5, Sc. 3, v. 26-27) Hermione may return, but she does so in a form that draws attention to the disappearance of her youth; as others have remarked, something else that has gone for good is Hermione's fertility and with it, the possibility of any other male heir. ${ }^{22}$

Swinburne is also perceptive in his discussion of "our last glimpse" of Mamillius: it is important that we last see him as we do. Swinburne doesn't

21. Charles Algernon Swinburne, A Study of Shakespeare, London, Chatto and Windus, 188 o, p. 222-223.

22. See for instance Janet Adelman, Suffocating Mothers: Fantasies of Maternal Origin in Shakespeare's Plays, Hamlet to The Tempest, New York and London: Routledge, 1992, 236. 
explain why seeing him thus strikes "a subtler and a deeper chord" than would the direct visualisation of the boy's terminal grief, but I think it is because, as with Ruth and Sarah in The Remains of the Day, the mode of their departure from the texts they inhabit thwarts the reader's expectations of more familiar aesthetic economies. To be sure, the two instances are not exactly alike: in The Winter's Tale there is a death-we know the end of Mamillius' story, even if we are not told enough about it-, whereas in The Remains of the Day we are left ignorant of the fate of Ruth and Sarah. The last we see of them (and indeed the only time they are ever brought even indirectly into our purview) is their departure from Mr. Stevens' pantry: "they left sobbing just as they had arrived," Stevens relates (RD, p. 150), and neither he nor we ever know what happened to them thereafter. This is important: as the draft Oxford English Dictionary entry for the new, political sense of the word "disappearance" makes explicit, it is not just the absence of the person who was once there which the word denotes, but the fact that their relatives do not know what has happened to them. ${ }^{23}$

This new, political concept of the word in other words, draws attention to a phenomenon which narrative shares with real life: in both closure (aesthetic or emotional,) is contingent on the communication-to the reader, to the relative-of sufficient knowledge or information about what happens to a person at the end. Realist fictions generally do provide that information, at least for the characters who are important enough for us to wonder about, but Ishiguro often does not: such "disappearances" are a repeated motif in his fictional worlds, and a measure of his distance from more realist narrative conventions (even if, paradoxically, it approximates an all too real zoth century phenomenon). ${ }^{24}$ We don't expect in fiction to be left quite so unenlightened about the fate even of such minor characters, just as we don't expect that the heir to the throne will die in the second act of a romance, let alone with such little warning, so little ceremony.

23. The March 2003 draft addition to the entry for the verb "disappear" reads: "Of a person: to go missing in suspicious circumstances; spec. (euphem.) to undergo abduction or arrest, esp. for political reasons, and subsequently to be detained or killed, without one's fate being made known." http://dictionary.oed.com/, consulted 29 August 2007.

24. Mariko and Sachiko disappear from A Pale View of Hills, New York, Putnam, 1982; When We Were Orphans, New York, A. A. Knopf, 2000, organised around the disappearance of Banks' parents, includes another brief encounter with a character whom the text almost immediately, and quite shockingly, abandons (the orphaned Chinese girl in the bombed out building in Shanghai). See Andrew Teverson, "Acts of Reading," for some remarks on the reader's role in Ishiguro's fiction compared with the reader's role in a realist narrative. 
The manner of the texts' disappearance of these characters ruptures our confidence in our generic expectations, using the bafflement of those expectations to render the text strange to us, and thus forcing us, as Brecht put it, to "think above the flow" of the text rather than "within" it. 25

So in a sense, although Swinburne doesn't explicitly say it, that resistance of the temptation to make "pathetic profit" from Mamillius is intimately connected with the last, and most profound, of the observations Swinburne makes about The Winter's Tale: that is, "that we remember [Mamillius] all the better because the father whose jealousy killed him and the mother for love of whom he died" (p. 223) appear to have forgotten him. If such disappearances thwart generic expectations and alienate us from the familiar comfort of a known aesthetic form, they also, to continue this Brechtian exploration, prevent us from experiencing the action of the drama or narrative with the character, forcing us instead to confront the implications of what we see, because the characters do not. What these texts do when they "disappear" their characters like this, is displace their memory from one media (the text itself, and the minds of the characters it contains) to another (the minds of the readers, or audience, outside the text). In so doing, they deny to their readers the consolation that they sometimes allow, in the end, to their protagonists. Those protagonists, or some of them, may indeed, as we've seen C. L. Barber and Richard P. Wheeler argue, manage to recover the lost beloved as an inner presence so that they are free to engage in new emotional cathexes, and move on. Perhaps this is true for Leontes, even, in some readings of the novel, for Stevens, resolved as he is to banter anew with

25. Bertolt Brecht, quoted in Raymond Williams, Drama from Ibsen to Brecht, Harmondsworth, Penguin, 1973, p. 321. Henceforth, references to this text will be indicated by the initials "DIв," followed by the page number, and placed in parentheses and placed in the body of the text. Williams does not say where he got this quotation from, other than to mention that it is "a phrase Brecht used looking back on the production of The Threepenny Opera." The Brechtian subtext to my argument here might at first sight seem ill-applied to Shakespeare and Ishiguro. But Williams traces the origins of the form of Brechtian drama from the drama of the English Renaissance "and especially from Shakespeare." (DIB, p. 330) And the following description of what Brechtian drama achieves resonates for Ishiguro's prose: "the experiences of transforming relationship and of social change are not included, and the tone and the conventions follow from this: men are shown why they are isolated, why they defeat themselves, why they smell of defeat and its few isolated, complicit virtues." (DIB, p. 331) 
his new employer, Mr. Farraday. ${ }^{26}$ But if we try to map this onto a Swinburnian reading of The Winter's Tale, with its crucial claim - that the loss from which the mourner can apparently move on is felt, for that reason, even more keenly by the reader who cannot share that easy sense of restitution, then the reader left in a more melancholy place, unable to leave the past behind in quite the way that the protagonist can.

In Stevens' case, his inability to acknowledge Ruth and Sarah other than elliptically, as someone else's mistake, raises other, deeper questions for the reader about responsibility and its limits. Most readers probably despair of Stevens when, having momentarily stopped "pretending" in the anguished lament with which I opened this essay, he retreats at the novel's conclusion into the same abdication of agency that he has displayed throughout the text. "After all," he asks the reader,

What can we ever gain in forever looking back and blaming ourselves if our lives have not turned out quite as we might have wished? The hard reality is, surely that for the likes of you and I, there is little choice other than to leave our fate, ultimately, in the hands of those great gentlemen at the hub of this world who employ our services. (RD, p. 244)

Once again, we encounter the invitation to disagreement ("but I am not a butler; I am not like you") embedded in the text here, in part to provoke the reaction that yes, there are other choices, and we should not leave our fate in the hands of others. Certainly my students, reading this passage, invariably (and often dismissively) resist Stevens' implication here, just as they lament his decision to return to Darlington Hall to practice bantering so that he can "pleasantly surprise" his employer on his return. But those same students who are so vehement in condemning Mr. Stevens for his retreat into the abdication of responsibility to greater gentlemen than he are also often prone to remark that since neither Mr. Stevens nor Miss Kenton have any power to change the fate of Ruth and Sarah, it doesn't really matter what they say or think. When I ask: "but isn't it better to do as Miss Kenton does, and speak out when something is wrong even if you can't do anything about it?" many of them reply: "what's the point?"

It disturbs me that year after year, the argument that changes most of the students' minds about whether speaking out matters is the following one. What if Mr. Stevens and Miss Kenton had both spoken out, and both threatened to resign, I ask them? Might Lord Darlington in that case not have weighed the

26. James Phelan, Mary Patricia Martin, “The Lessons of 'Weymouth:' Homodiegesis, Unreliability, Ethics and The Remains of the Day," in David Herman (ed.), Narratologies: New Perspectives on Narrative Analysis. Columbus, Ohio State University Press, 1999, p. 107. 
worth of sacking Ruth and Sarah against the value of his two most senior employees to the smooth running of his household? Perhaps together Mr. Stevens and Miss Kenton might have more power than they think they do? And even if Lord Darlington were to prove immovable in the face of their resistance, would the consequences of speaking out be so very bad? Miss Kenton, lamenting her failure to resign, asks herself:

"Where could I have gone? I have no family [...] I did tell myself [...] I would soon find some new situation. But I was so frightened [... ] Whenever I thought of leaving, I just saw myself going out there and finding nobody who knew or cared about me. There, that's all my high principles amount to." (RD, p. 152-153)

But had they both spoken out, neither Miss Kenton nor Mr. Stevens would have had to leave alone, since both would have left together. Much might have followed from speaking out, in that case: this road might have left them together, not apart, in the remains of their days. That this is an alternative envisaged in but unspoken by the novel is reinforced by what Mr. Stevens refers to immediately after as "a curious corollary to that whole affair: namely, the arrival of the housemaid called Lisa" (RD, p. 154) who ends up vanishing from the house some eight months later, eloping with the second footman. (RD, P. 157)

It is not that I dislike this utopian alternative, or the way the novel plays out the implications of this road not taken. It's perhaps not the subtlest aspect of The Remains of the Day, but most of the propositions that it appears designed to illustrate are not tendentious: that collective action is more efficacious than acting alone; that political and personal relationships and actions are alike in that they should both be structured by openness and honesty. Less self-evidently true is the correspondence between openness and happy endings that this alternative narrative trajectory implies. Yet it is not the truth or falsehood of the claims that troubles me, but the degree to which they (and apparently they alone) can shift the students' opinion about whether or not Mr. Stevens should speak out. There is something very worrying about the fact that the only argument that can persuade a large number of young adults to consider it is worthwhile speaking out is a consequentialist one. ${ }^{27}$ For surely, irrespective of what might have happened had Mr. Stevens and Miss Kenton both left when Ruth and Sarah did, the novel also suggests that not to speak out when one should is to open the door to the possibility of making someone else's mistakes. This is perhaps what makes

27. In this their response characterizes a pervasive contemporary instrumentalism which primarily values what gets results, and which often hides behind a veneer of "professionalism." There is more work to be done on the discourse of professionalism in Remains, and its relation to modes of professionalism in the contemporary world. 
the students' response so disturbing, and the conversation on the bench at Weymouth pier so poignant: the real state of affairs is not the impossibility of making someone else's mistakes, but the difficulty of being independent enough to make one's own. If this is so, Mr. Stevens' relation to authority is not one which is so very different to that of most ordinary people, and his dilemmas stand for those which we all confront. To adapt what Raymond Williams said about The Good Woman of Sezuan, "it is not fixed goodness against fixed badness" (DIB, p. 323) that is anatomised in The Remains of the Day: even Lord Darlington, as Stevens says, wasn't "a bad man," and nor is Stevens himself.

This is complex, rather than simple seeing, to borrow from Brecht once again (DIB, P. 323): The Remains of the Day foregrounds the complexity of the relations between thinking something, saying something, and doing something; 94 of recognising what is wrong, and acknowledging it, even if one cannot change it, or do anything about it. Disappearance is central to that lesson. If I ask my students whether we should then forget Ruth and Sarah as Mr. Stevens appears to have done at the end of the text, even those most vehement about the pointlessness of thinking or uttering resistance to something in the absence of the ability to change it reply "no," even though their memory of the character changes nothing. Perhaps they understand that as Walter Benjamin once remarked, "every image of the past that is not recognised by the present as one of its own concerns threatens to disappear irretrievably." ${ }^{\prime 28}$ And perhaps the last paradox, then, is that the displacement of the memory of the disappeared from the world of the text into the mind of the reader does in the end change something, if only the minds of those convinced before that thought without consequence is futile.

28. Walter Benjamin, "Thesis on the Philosophy of History" [1940], quoted in Cynthia Wong, Kazuo Ishiguro, Tavistock, Northcote House, 2000, p. 50. 